Hydrol. Earth Syst. Sci., 18, 1239-1249, 2014

www.hydrol-earth-syst-sci.net/18/1239/2014/

doi:10.5194/hess-18-1239-2014

(c) Author(s) 2014. CC Attribution 3.0 License.

\title{
Droughts and floods over the upper catchment of the Blue Nile and their connections to the timing of EI Niño and La Niña events
}

\author{
M. A. H. Zaroug ${ }^{1,2}$, E. A. B. Eltahir ${ }^{3}$, and F. Giorgi ${ }^{1}$ \\ ${ }^{1}$ International Center for Theoretical Physics, Earth System Physics, Trieste, Italy \\ ${ }^{2}$ Dinder Center for Environmental Research, Khartoum, Sudan \\ ${ }^{3}$ Massachusetts Institute of Technology, Civil and Environmental Engineering, Cambridge, USA
}

Correspondence to: M. A. H. Zaroug (modathir_23@yahoo.com)

Received: 8 August 2013 - Published in Hydrol. Earth Syst. Sci. Discuss.: 21 August 2013

Revised: 29 January 2014 - Accepted: 3 February 2014 - Published: 31 March 2014

\begin{abstract}
The Blue Nile originates from Lake Tana in the Ethiopian Highlands and contributes about $60-69 \%$ of the main Nile discharge. Previous studies investigated the relationship of sea surface temperature (SST) in the Pacific Ocean (Niño 3.4 region) to occurrence of meteorological and hydrological droughts in the Nile Basin. In this paper we focus on the dependence of occurrence of droughts and floods in the upper catchment of the Blue Nile on the timing of El Niño and La Niña events. Different events start at different times of the year and follow each other, exhibiting different patterns and sequences. Here we study the impact of these timing and temporal patterns on the Blue Nile droughts and floods. The comparison between the discharge measurements (1965-2012) at the outlet of the upper catchment of the Blue Nile and the El Niño index shows that when an El Niño event is followed by a La Niña event, there is a $67 \%$ chance for occurrence of an extreme flood. Furthermore, we also found that $83 \%$ of El Niño events starting in April-June resulted in droughts in the upper catchment of the Blue Nile. Although the current study is limited by the reduced number of samples, we propose that observations as well as global model forecasts of SST during this season could be used in seasonal forecasting of the Blue Nile flow.
\end{abstract}

\section{Introduction}

The Nile is the longest river in the world, with a length of $6650 \mathrm{~km}$, and it flows through 10 countries (Jury, 2004). The two main tributaries, the White Nile and Blue Nile, join to form the main Nile River in Khartoum, and the seasonal Atbara River joins the Nile approximately $500 \mathrm{~km}$ downstream. The Blue Nile originates from Lake Tana in the Ethiopian Highlands, at elevations of 2000-3000 m, and contributes about $60-69 \%$ of the main Nile discharge (Dumont, 1986). The upper Blue Nile River basin is $176000 \mathrm{~km}^{2}$ in area (Conway, 2000). The rainfall regime follows the seasonal solar heating above the Ethiopian Plateau, and the rainy season extends approximately from June to September. The two main tributaries of the Blue Nile in Sudan are the Rahad and Dinder. The rainy season in Ethiopia is known locally as Kiremt, (Seleshi and Zanke 2004), and rainfall is highly variable both temporally and spatially (Gissila et al., 2004).

The Blue Nile sustains the life of millions of people in Ethiopia, Sudan and Egypt. Rainfall has a great impact on the social and economic life in the region. Scarcity of rainfall leads to drought, while excessive intense rainfall may lead to flooding. For example, during the 1984 drought in Sudan, Khartoum received only $4.7 \mathrm{~mm}$ of rain between May and October (Eltayeb, 2003). This led to crop failure and consequently a famine hit Sudan, leading to massive migration of people in search of food and water (Teklu, 1991). Floods reflect the other extreme in rainfall fluctuations. There are many factors which affect the severity of a flood, such as terrain slope, soil type and the amount of water in the soil. On 4 August 1988, Khartoum received $210 \mathrm{~mm}$ of rainfall at Khartoum Central during a $24 \mathrm{~h}$ period (Sutcliffe et al., 1989). (The previous highest daily rainfall measured at Khartoum since records began in 1899 was $88 \mathrm{~mm}$ on 31 July 1920; Hulme and Trilsbach, 1989.) This situation became 
disastrous when the Nile level also rose about $7 \mathrm{~m}$ above normal, which led to wide-spread property damage. A rainfall of $200 \mathrm{~mm}$ at Khartoum was estimated to have a return period of about 500 years by Sutcliffe et al. (1989). These two natural extreme disasters were associated with significant anomalies in the Pacific sea surface temperature (SST): the El Niño (1983) and La Niña (1988) events. An El Niño/La Niña is the phenomenon in the equatorial Pacific Ocean characterized by a positive/negative sea surface temperature (SST) defined as a 3-month average of SST departures from normal (for the 1971-2000 climatology) in the Niño 3.4 region $\left(5^{\circ} \mathrm{N}-5^{\circ} \mathrm{S}, 120^{\circ}-170^{\circ} \mathrm{W}\right)$ greater than or equal in magnitude to $0.5 /-0.5^{\circ} \mathrm{C}$ for a minimum of 6 consecutive months or longer (Trenberth, 1997). The Southern Oscillation Index (SOI) is a measure of air pressure difference between Tahiti in the east and Darwin, Australia to the west as compared to the historical average of the same difference. Negative differences indicate El Niño conditions as lower pressure in the eastern Pacific and associated to warmer water and weakened easterly trade winds, and positive SOI corresponds to negative SST index and La Niña.

During the last few decades, there has been wide recognition that natural oscillations in areas of the Pacific Ocean have a significant impact on the patterns of weather and climate around the world (e.g. Amarasekera et al., 1997; Eltahir, 1996; Zaroug et al., 2014). The most dominant among these oscillations is known as the El Niño-Southern Oscillation (ENSO), which has a return period of about 4 years, varying from 2 to 7 years. Though distant from Africa, ENSO is significantly correlated with rainfall variations over the eastern side of the African continent, but the signs of the correlations and their phase relative to the seasonal cycle vary from region to region (Camberlin et al., 2001). Eltahir (1996) found that $25 \%$ of the natural variability in the annual flow of the Nile is associated with ENSO and proposed using this observed correlation to improve the predictability of the Nile floods. Wang and Eltahir (1999) recommended an empirical methodology for medium- and long-range ( $\sim 6$ months) forecasting of the Nile floods using ENSO information, while Amarasekera et al. (1997) showed that ENSO episodes are negatively correlated with the floods of the Blue Nile and Atbara rivers, which originate in Ethiopia. De Putter et al. (1998) presented a study of decadal periodicities of the Nile River historical discharge of the Roda Nilometer (Cairo, Egypt) and suggested that high-frequency peaks could be linked to ENSO. Abtew et al. (2009) analyzed monthly rainfall observations from a 32-rain gauge monitoring network in the upper Blue Nile Basin and found that high rainfall is likely to occur during La Niña years and low rainfall conditions during El Niño years. He also found that extremely dry years are highly likely to occur during El Niño years and extremely wet years are highly likely to occur during La Niña years. Finally, Seleshi and Zanke (2004) reported that June-September rainfall in the Ethiopian Highlands is positively correlated to the Southern Oscillation Index (SOI) and negatively correlated to the equatorial eastern Pacific SST. An advantage of knowing the timing of El Niño and La Niña is that they have been shown to be generally predictable for around 6-12 months in advance (Barnett et al., 1988; Latif et al., 1998; Barnston et al., 1994; Chen et al., 2004; Chen and Cane, 2008). So, if we find a strong correlation between ENSO and the flow of the upper catchment of the Blue Nile, this will increase the ability to predict the flow pattern in the Blue Nile.

Several studies attempted to use oceanic and atmospheric variables as predictors in seasonal hydrologic forecasting over East Africa (Mutai et al., 1998; Hastenrath et al., 2004; Philippon et al., 2002; Yeshanew and Jury, 2007; Mwale and Gan, 2005; Williams and Funk, 2011, 2010), however none of these studies focused on the June-September rainfall in Ethiopia. In this study, we analyze river flow and rainfall observations with the goal of evaluating the impact of El Niño on drought and flood conditions in the upper catchment of the Blue Nile. Flood and drought in the context of this paper refer to high and low flows. Not all El Niño and La Niña events are the same (see Fig. 1), they have different timings and characters. In fact, different events start at different times of the year and their sequence exhibits different patterns. In this paper we focus on the dependence of occurrence of droughts and floods in the upper catchment of the Blue Nile on the timing and sequence of El Niño and La Niña events. In particular, we attempt to identify the sequence of Pacific Ocean seasonal SST conditions that significantly affect drought and flood conditions over Ethiopia in order to provide recommendations for possible use as input to seasonal water resources forecasting systems. This would have great economic and social value for the management of water resources in the region.

\section{Data and methods}

Discharge measurements between 1965 and 2012 from Eldiem station (Fig. 2), located at the border between Sudan and Ethiopia about $120 \mathrm{~km}$ upstream from Elrosieres dam (Fig. 2), are used in this study. The gauge station measures water level and discharge at the outlet of the upper catchment of the Blue Nile. The data at Eldiem station from 1997 to 2001 were missing, and these missing data points were filled by using the nearest station to Eldiem, Elrosieres, noting that there are no contributing tributaries between the two stations. The contribution of inflow/losses to the river between Eldiem and Elrosieres is small compared to the contribution of the runoff from rainfall in the whole upper catchment of the Blue Nile. In this study we accumulate the daily discharge of June, July, August, and September at Eldiem station, and the accumulated daily discharge at Elrosieres during the same period is almost similar to Eldiem. Conway (1997) made a water balance model of the upper Blue Nile in Ethiopia. He used Elrosieres record for 1912-1963, before construction of the Elrosieres dam, and Eldiem for the period 1964-1987 to 


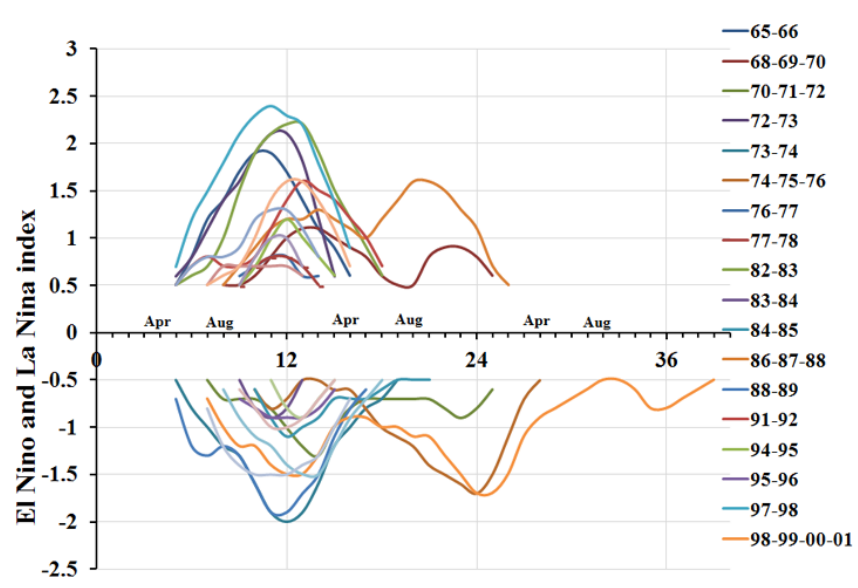

Fig. 1. El Niño and La Niña timing.

provide a continuous time series. He found good agreement between two gauges during their period of overlap (annual correlation $=0.97$ ). The discharge data represents the catchment hydrology better than the rainfall data from scattered set of sparsely distributed stations. In fact, Duethmann et al. (2013) concluded that the rainfall data has a relatively large uncertainty due to errors in measurement, wind, and high spatial variability of precipitation in the mountainous regions. The density of rain gauge networks is often low, and the gauges are often unevenly distributed.

For this reason, we use multiple precipitation data sets (Zaroug et al., 2013): the global data set of monthly precipitation from the Global Precipitation Climatology Project (GPCP) version 2.2 (Huffman et al., 2011), which is a satellite/gauge-merged rainfall product available from January 1979 to December 2010 with a resolution of $2.5^{\circ}$; the Climate Research Unit (CRU, land only) $0.5^{\circ} \times 0.5^{\circ}$ resolution monthly precipitation data set (Mitchell et al., 2004), which is a purely gridded gauge product; and the University of Delaware (UDEL) monthly global gridded high-resolution station (land) data $\left(0.5^{\circ} \times 0.5^{\circ}\right.$ resolution) available from 1900 to 2010 (ESRL, 1900-2010). While it is true that GPCP spatial resolution is relatively coarse, this data set extends for a long period of about 30 years. This is much longer than other data sets such as TRMM, which has a higher spatial resolution but significantly shorter length of about 15 years.

In order to identify El Niño conditions, the Niño 3.4 index between 1965 and 2012 was downloaded from the NOAA website (NOAA, 2014). The data from the Niño 3.4 region was preliminarily analyzed in relation to several precipitation observational data sets.

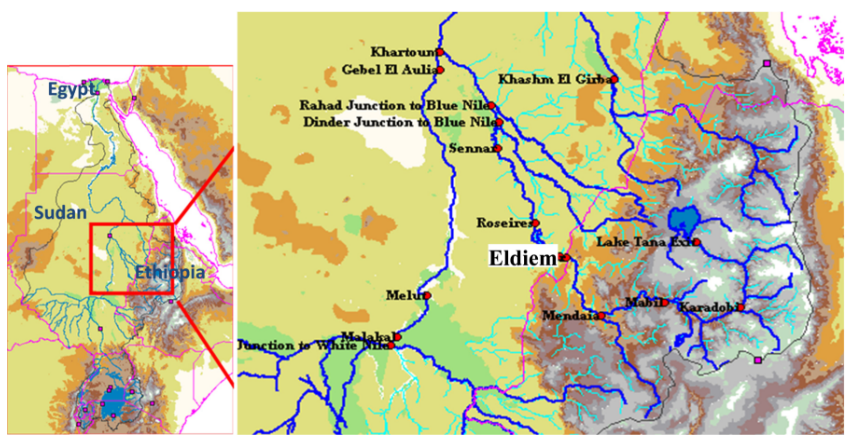

Fig. 2. The topography and geography of cities in the region.

\section{Results and discussion}

\subsection{Relation of Pacific SST and discharge at Eldiem station}

Figure $3 \mathrm{c}$ shows the discharge at Eldiem station and its association with El Niño and La Niña years, with the upper panels presenting two specific episodes (Fig. 3a and b). As can be seen from these figures, El Niño years such as 1972 and 1987 are associated with low discharge, while La Niña years, for example 1988, are associated with relatively high discharge. This result is more clearly and quantitatively depicted in Fig. 4, which shows the monthly discharge (JanuaryDecember) averaged over all El Niño $(1965,1968,1969$, 1972, 1982, 1983, 1986, 1987, 1991, 1992, 1995, 1997, 2002, 2004, and 2009), La Niña (1970, 1971, 1973, 1974, 1975, 1985, 1988, 1989, 1998, 1999, 2000, 2007, 2008, and 2010) and normal years $(1966,1967,1976,1977,1978$, 1979, 1980, 1981, 1984, 1990, 1993, 1994, 1996, 2001, 2003, 2005, 2006, 2011, and 2012). This confirms the results of previous studies that El Niño is mostly associated with below-average rainfall, and La Niña with above-average rainfall (Eltahir, 1996; Wang and Eltahir, 1999; Amarasekera et al., 1997; De Putter et al., 1998; Camberlin et al., 2001; Abtew et al., 2009).

The JJAS discharge anomalies for the full analysis period are shown in Fig. 5, along with some thresholds: any discharge anomaly above $6.971 \mathrm{~km}^{3}, 1 \times$ standard deviation, is considered as extreme flood, and any discharge anomaly below $-6.971 \mathrm{~km}^{3}$ as extreme drought; any discharge anomaly between $3.486 \mathrm{~km}^{3}(0.5 \times$ standard deviation $)$ and $6.971 \mathrm{~km}^{3}$ is considered as flood conditions, and any discharge anomaly between -3.486 and $-6.971 \mathrm{~km}^{3}$ as drought. Finally, any discharge anomaly between -3.486 and $3.486 \mathrm{~km}^{3}$ is considered as normal. The normal events cover about $38 \%$ of the total number of years, while the number of drought and flood events contributes another $30 \%$, and extreme drought and flood contribute some $32 \%$. This classification is in line with observed floods and droughts in this region, as well as with the classification of the Ministry of Water Resources and Electricity of Sudan (MOWRE) (2011). In Fig. 5, nine 
a)

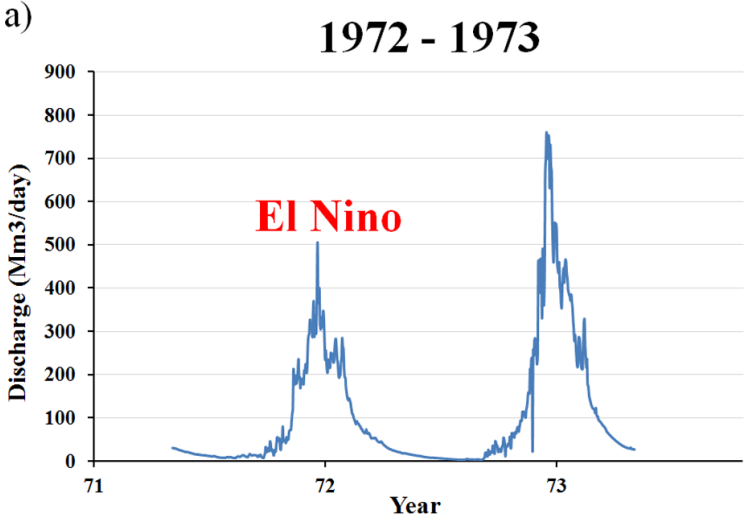

b)

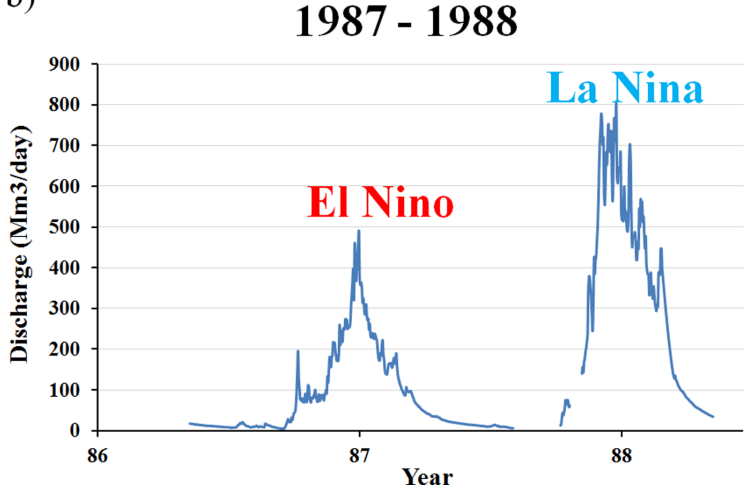

c)

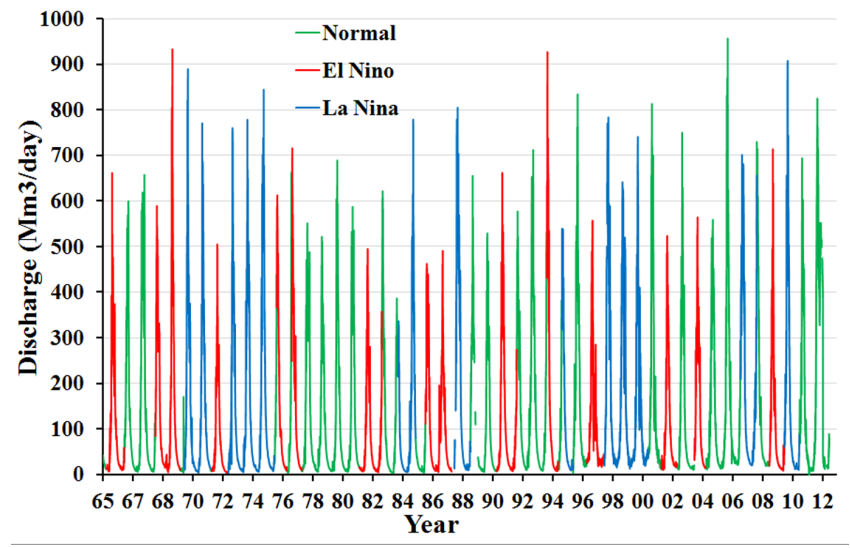

Fig. 3. The discharge of the Blue Nile at Eldiem station (19652012) and its association with El Niño and La Niña years in (c), red represents El Niño event periods, blue represents La Niña event periods, and green represents normal event periods. (a) and (b) are a zoom on some El Niño and La Niña years.

extreme flood years can be identified, and among them there are three at or close to record floods $(1988,2006$, and 2007). There are nine cases of extreme drought, five floods, and seven droughts.

The coefficient of correlation and coefficient of determination are calculated for the linear fit between Niño 3.4

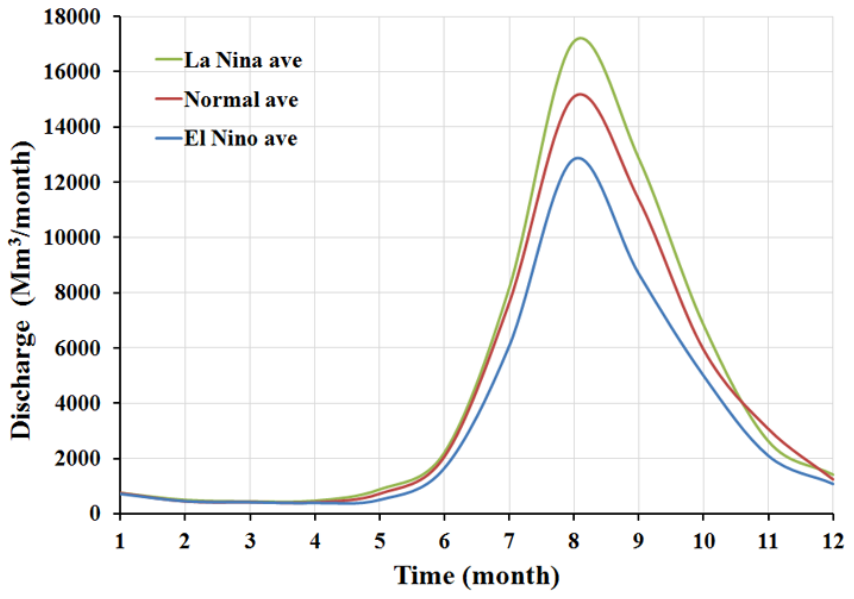

Fig. 4. Monthly discharge at Eldiem station averaged during El Niño (1965, 1968, 1969, 1972, 1982, 1983, 1986, 1987, 1991, 1992, 1995, 1997, 2002, 2004 and 2009), La Niña (1970, 1971, 1973, 1974, 1975, 1985, 1988, 1989, 1998, 1999, 2000, 2007, 2008 and 2010) and normal years (1966, 1967, 1976, 1977, 1978, 1979, 1980, 1981, 1984, 1990, 1993, 1994, 1996, 2001, 2003, 2005, 2006, 2011 and 2012).

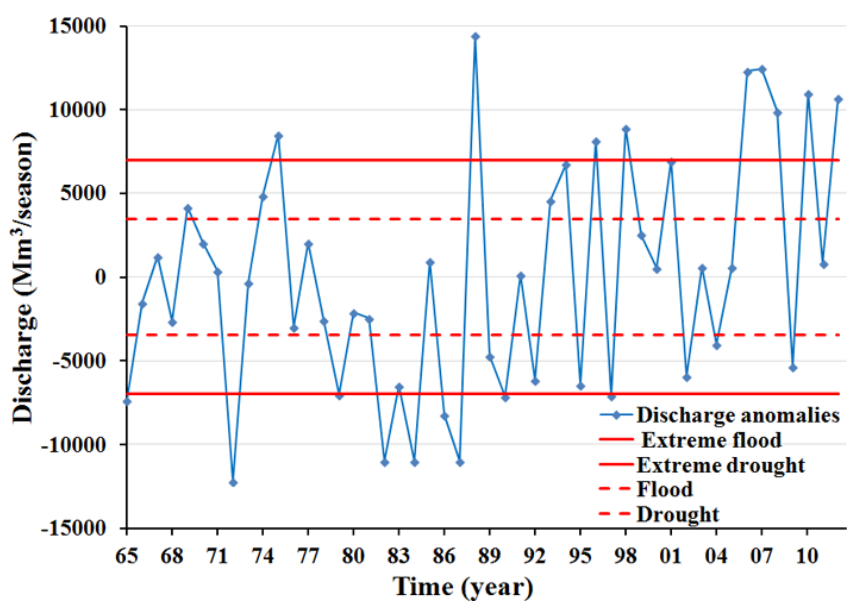

Fig. 5. The discharge anomalies at Eldiem station averaged over JJAS (1965-2012), the red line represents the threshold for the extreme flood/drought, and the dashed red line represents the threshold for drought/flood.

and discharge anomalies in each season as illustrated in Table 1. Figure 6 shows examples of the relation between SST anomalies in the Niño 3.4 region in different seasons and JJAS discharge anomalies at Eldiem station. The scatter plots are made for Niño 3.4 versus discharge anomalies for different seasons as shown in Fig. 7. The period extended from 1965 to 2012. A negative correlation between the Niño 3.4 SST anomalies in (JFM, AMJ, and ASO) and the JJAS discharge anomalies at Eldiem is evident in the panel of Fig. 6 and Table 1. For example, the large El Niño of 1987 is associated with below-average discharge and the La Niña of 1988 is clearly associated with above-average discharge. 
Table 1. The coefficient of determination and correlation for the linear fit between Niño 3.4 index in different seasons and the JJAS discharge anomalies at Eldiem station for the period 1965-2012.

\begin{tabular}{lcc}
\hline & \multicolumn{2}{c}{ JJAS precipitation } \\
SST index & $R^{2}$ & Correlation \\
\hline JFM & 0.01 & -0.08 \\
AMJ & 0.15 & -0.39 \\
ASO & 0.29 & -0.53 \\
\hline
\end{tabular}

This negative correlation is less evident in the case of JFM (Fig. 6a and Table 1) and, to a lesser extent, AMJ (Fig. 6b and Table 1), and higher in ASO (Fig. 6c and Table 1) SST anomalies. The same plot was made with SST anomalies for other seasons; FMA, MAM, MJJ, JJA and JAS (not shown here), and FMA and MAM also showed lower correlations compared to the MJJ, JJA and JAS anomalies. The highest correlation was found during JJA and JAS $(-0.56$, not shown here). Figure 6 thus illustrates that the rainfall in the upper Blue Nile River catchment is highly sensitive to the SST during AMJ to ASO. In this analysis we look at the correlation and coefficient of determination for the whole period (1965-2012) regardless of El Niño, La Niña or normal years. These results are not significantly different from the results of Eltahir (1996), who used the annual flow in the Nile River at Aswan from 1872 to 1972 and found the highest correlation $(-0.5)$ during SON and -0.45 during JJA with different SST regions. Amarasekera et al. (1997) calculated the correlation of the Blue Nile using the same SST index as Eltahir (1996), and found the correlation -0.44 for JJA and SON. Although in this study we used Niño 3.4 index with a different period, our results are in line with the other studies.

The impact of the start date of El Niño on the drought of the upper catchment of the Blue Nile is further illustrated in Table 2. The first column in Table 2 shows the starting season of El Niño, the second and third columns then indicate whether there was an extreme drought or drought episode during the same year (JJAS) over the upper catchment of the Blue Nile, while the fourth column shows whether there was no drought. The flow year column shows the start year of each El Niño event, while the length column refers to the duration of the El Niño episode expressed in number of months.

Table 2 shows that for the six episodes in which El Niño started in AMJ, an extreme drought occurs four times, and one time drought conditions prevails, with only one year having normal conditions. When El Niño starts in AMJ the likelihood of occurrence of droughts is $83 \%$. We acknowledge that this percentage is estimated based on a limited sample of six events only. When El Niño starts in JJA, there are two droughts out of two events. More mixed results are found when El Niño starts in JAS (cases of both drought and no drought equally distributed). Finally, when El Niño starts late in ASO, it tends to be relatively short $(1976,1977,1994$, and a)

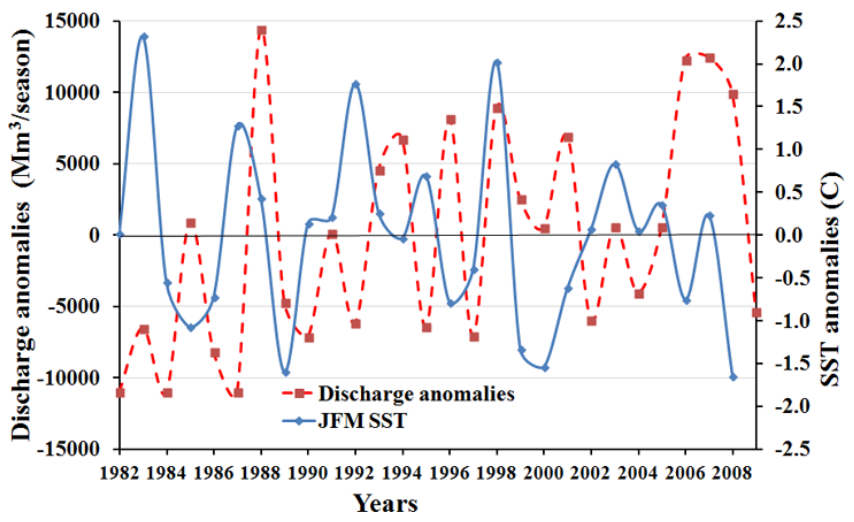

b)

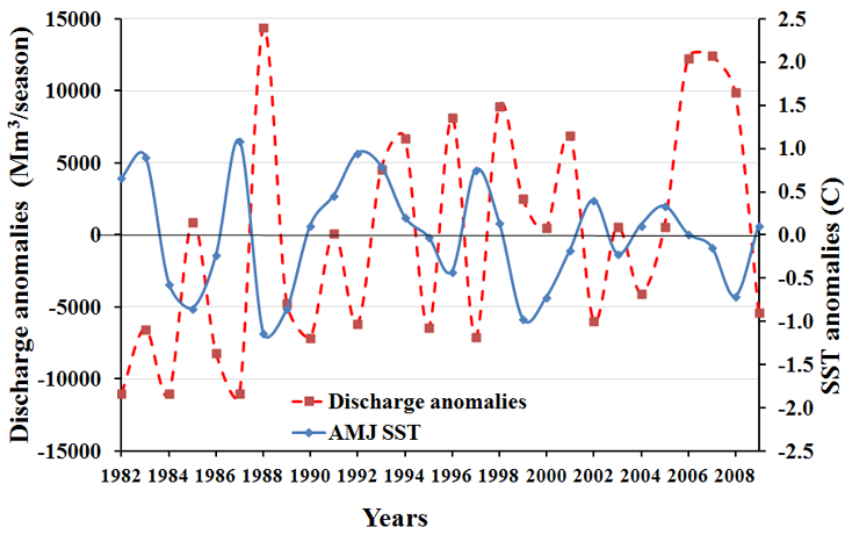

c)

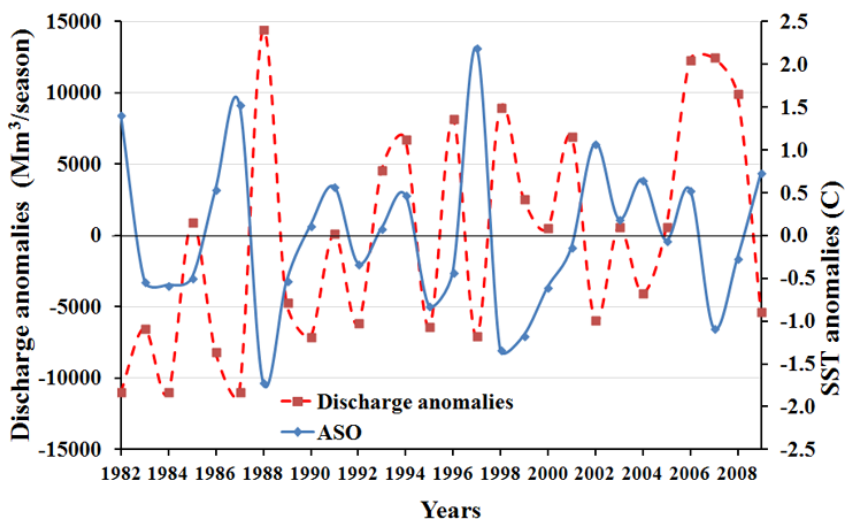

Fig. 6. The SST anomalies during (a) JFM, (b) AMJ, and (c) ASO in Niño 3.4 region and the discharge anomalies in Eldiem station during JJAS from 1982 to 2009.

2006), and for the years available there is no drought event (in the same year) for four occurrences (while there was one case of flood and one of extreme flood). However, when the correlation was calculated for the all years of ASO regardless of El Niño, La Niña and normal years during ASO, it was -0.53 as illustrated in Table 1. Eltahir (1996) and Amarasekera et al. (1997) also found high correlation during this 
Table 2. The effect of the start date of El Niño on the drought of the upper catchment of the Blue Nile during JJAS of the same year.

\begin{tabular}{lccccc}
\hline $\begin{array}{l}\text { Start of } \\
\text { El Niño }\end{array}$ & $\begin{array}{c}\text { Extreme } \\
\text { drought }\end{array}$ & Drought & $\begin{array}{c}\text { No } \\
\text { drought }\end{array}$ & $\begin{array}{c}\text { Flow } \\
\text { year }\end{array}$ & $\begin{array}{c}\text { Length } \\
\text { (season) }\end{array}$ \\
\hline AMJ (1965) & $\sqrt{ }$ & & & 1965 & 12 \\
AMJ (1972) & $\sqrt{ }$ & & & 1972 & 11 \\
AMJ (1982) & $\sqrt{ }$ & & & 1982 & 14 \\
AMJ (1991) & & & $\sqrt{ }$ & 1991 & 14 \\
AMJ (1997) & $\sqrt{ }$ & & & 1997 & 12 \\
AMJ (2002) & & $\sqrt{ }$ & & 2002 & 10 \\
JJA (2004) & & & & 2004 & 7 \\
JJA (2009) & & & & 2009 & 10 \\
JAS (1968) & & & $\sqrt{ }$ & 1968 & 18 \\
& & & $\sqrt{ }$ & 1969 & \\
JAS (1986) & $\sqrt{ }$ & & & 1986 & 19 \\
& $\sqrt{ }$ & & & 1987 & \\
ASO (1976) & & & $\sqrt{ }$ & 1976 & 6 \\
ASO (1977) & & & $\sqrt{ }$ & 1977 & 6 \\
ASO (1994) & & $\sqrt{ }$ & 1994 & 7 \\
ASO (2006) & & & & \\
\hline
\end{tabular}

season. In this study, however, the added value of our analysis points to the fact that when El Niño starts in ASO, it has no impact on the Blue Nile flow. The results of Table 2 thus suggest that there is a relation between El Niño events that start in AMJ and drought conditions in Ethiopia, while no effect is found when El Niño events start late in the year in ASO.

La Niña is normally associated with floods in the upper catchment of the Blue Nile (Eltahir, 1996; Wang and Eltahir, 1999; Amarasekera et al., 1997). In Table 3 the role of the start date of the La Niña season is explored in terms of its relation with flood conditions in the upper catchment of the Blue Nile (in the same year). The first column in Table 3 shows the season of the start of La Niña, and from Table 3 it is clear that La Niña events can last for up to three years, as in 1973-1975 and 1998-2000.

When La Niña started in AMJ of 1988, there was one extreme flood (in the same year), when it started in AMJ of 1973 and extended for 3 years, there was no flood (in the same year), and one flood and one extreme flood in the following years. When La Niña started in JJA, there was no flood in 1970 and there were extreme flood conditions in 1998 and 2010. When La Niña started in JAS of 2007, there was an extreme flood. When La Niña started late in ASO, it tended to be also relatively short (1983, 1995, and 2011), there were no floods recorded, and in one case (2011) there was even a strong drought. Similar to the analysis of the start of El Niño during ASO, there is no impact on the upper Blue Nile flow. Therefore, in general, when La Niña started in AMJ, JJA and JAS, $67 \%$ of the time there was a flood or extreme flood, showing that the rainfall and the monsoon in this catchment is sensitive to AMJ, JJA and JAS SST in the
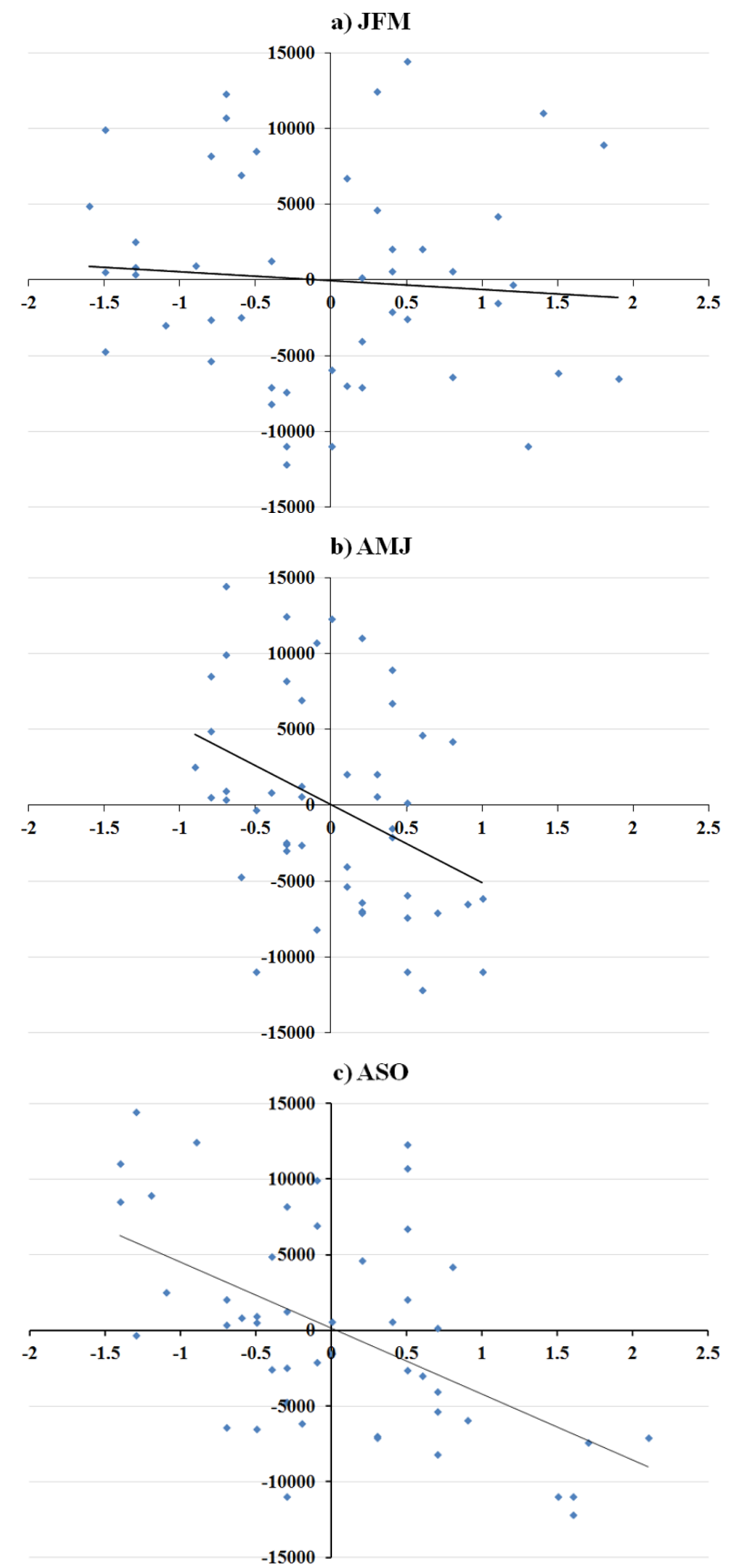

Fig. 7. The scatter plots for the discharge anomalies at Eldiem station versus Niño 3.4 during (a) JFM, (b) AMJ, and (c) ASO, for the period 1965-2012.

Pacific Ocean. The $67 \%$ is calculated as follows:

$\frac{4(\text { extreme flood or flood events during the first year of a La Niña event })}{6 \text { (number of La Niña events) }}=67 \%$.

In this analysis it is important to highlight the limited number of events that are used to calculate this percentage. 
Table 3. The effect of the start of La Niña in the flood of the upper catchment of the Blue Nile during JJAS of the same year.

\begin{tabular}{lccccc}
\hline $\begin{array}{l}\text { Start of } \\
\text { La Niña }\end{array}$ & $\begin{array}{c}\text { Extreme } \\
\text { flood }\end{array}$ & Flood & $\begin{array}{c}\text { No } \\
\text { flood }\end{array}$ & $\begin{array}{c}\text { Flow } \\
\text { year }\end{array}$ & $\begin{array}{c}\text { Length } \\
\text { (season) }\end{array}$ \\
\hline AMJ (1973) & & $\sqrt{ }$ & $\sqrt{ }$ & 1973 & 36 \\
& $\sqrt{ }$ & & & 1974 & \\
AMJ (1988) & $\sqrt{ }$ & & & 1988 & 13 \\
JJA (1970) & & $\sqrt{ }$ & 1970 & 18 \\
& & $\sqrt{ }$ & 1971 & \\
JJA (1998) & $\sqrt{ }$ & & & 1998 & 33 \\
& & $\sqrt{ }$ & 1999 & \\
& & & 2000 & \\
JJA (2010) & $\sqrt{ }$ & & 2010 & 10 \\
JAS (2007) & $\sqrt{ }$ & & & 2007 & 11 \\
& $\sqrt{ }$ & & & 2008 & \\
ASO (1983) & & $\sqrt{ }$ & 1983 & 5 \\
ASO (1995) & & $\sqrt{ }$ & 2011 & 7 \\
ASO (2011) & & & & 7 \\
\hline
\end{tabular}

As mentioned in the introduction, in this paper we also explore the importance of the sequence of El Niño followed by La Niña in relation to flood conditions in the upper Blue Nile catchment. For the last 40 years when El Niño was immediately followed by La Niña conditions, there were extreme flood records in the upper catchment of the Blue Nile (1988, 1998, 2007, and 2010), in other words, $67 \%$ of the cases of extreme flood (Table 4). The minus sign in Table 4 represents the end of the El Niño period, and the plus sign represents the start of La Niña. If we look at the period from the 1980s to present, it can be concluded that when El Niño is followed by La Niña, in the four recent sequential events there was extreme flood in the Blue Nile. It is an important result with a crucial implications for water managers when El Niño quickly followed by La Niña, for example El Niño of 1998 and 2010 ended in MAM and La Niña started quickly in JJA with an extreme flood. It should be emphasized, however, that these results are based on a limited sample size (only six events). In this analysis we excluded the events of 1983 and 1995, because La Niña started late in ASO. From the previous analysis in Tables 2 and 3, it is evident that when El Niño or La Niña starts late in the year, it does not impact rainfall in the upper Blue Nile catchment.

This study highlights for the first time the likelihood of the occurrence of record flood flow in the upper catchment of the Blue Nile when El Niño is followed by La Niña. However, we must consider the limitation of the few cases studied. The strength of El Niño seems to have no impact on the extreme flood, because, for example, the 1997-1998 El Niño was one of the highest El Niño, but 2006-2007 El Niño was a normal El Niño.
Other SST anomalies outside of the Pacific Ocean may have an impact in the Blue Nile flow; they may enhance or reduce the precipitation in the upper Blue Nile. The earlier studies which found the connection between the Nile floods and summer monsoon rainfall over India was examined in Bhatt (1989) and Whetton and Rutherfurd (1994). Camberlin (1997) found a teleconnection between the Indian monsoon and the summer rainfall in East Africa, and the predictors for the Indian monsoon can themselves be used as predictors for East African rainfall. Negative sea level pressure anomalies in Bombay are followed by abundant rainfall in Ethiopian Highlands, while positive sea level pressure anomalies lead to below-average rainfall. Awadalla and Rousselle (1999) attempted to predict the Nile River inflows to the High Aswan Dam (HAD) in Egypt. They found significant improvement in model skill by incorporating, beside the Pacific and Atlantic SST, the Indian SST. Eldaw et al. (2003) showed that the Indian Ocean's SSTs and the Blue Nile River flows are generally negatively correlated, but sometimes, certain regions of the Indian Ocean (e.g., the Arabian Sea and the sea north of Australia) are positively correlated.

Seleshi (1991) found that one of the causes of Ethiopian rainfall is the strong movement of moist air from the high southwest Gulf of Guinea to the low northeast center of Arabia. Gray et al. (1992) found that extra ASON precipitation at Guinea may lead to more rain in the Sahel during the following year, and on the other hand, a dry ASON period may lead to drought in the Sahel several months later. Vizy and Cook (2001) found that both warming and cooling of the Gulf of Guinea in summer suppress convection over northeast Africa. Eldaw et al. (2003) found that the Blue Nile River JASO flow is significantly and positively correlated with the previous year's ASON Guinea precipitation, and the Guinea precipitation is another potential predictor of the Blue Nile River flows, with 11 months of lead time and $r=0.63$ for the period 1953-1989. The following example illustrates the added value of knowing the timing of El Niño and La Niña for predicting extreme floods. In the 48 years of analysis (1965-2012) there were 9 extreme floods, so the chance of having an extreme flood in any year during this period was $19 \%$. If however we have additional knowledge about the occurrence of a La Niña year, this possibility of an extreme flood increases. In fact, during this period we have 14 La Niña years, and among them 6 extreme floods were observed. As shown in Table 4, when El Niño is followed by a La Niña year (with La Niña not starting late in ASO or ending early in MAM) the chance of getting and extreme flood increased to $67 \%$.

\subsection{Relation of Pacific SST and observed precipitation in the upper Blue Nile catchment}

In the previous sections we evaluated the relations between Niño 3.4 SST anomalies and discharge at the upper catchment of the Blue Nile. We now turn our attention to the 
Table 4. El Niño followed by La Niña and occurrence of extreme flood conditions.

\begin{tabular}{|c|c|c|c|c|c|c|c|c|c|c|}
\hline Year & DJF & JFM & FMA & MAM & AMJ & MJJ & JJA & JAS & ASO & Remark \\
\hline 1970 & - & & & & & & + & & & Normal (above average) \\
\hline 1973 & & & - & & + & & & & & Normal \\
\hline 1988 & & - & & & + & & & & & Extreme flood \\
\hline 1998 & & & & - & & & + & & & Extreme flood \\
\hline 2007 & - & & & & & & & + & & Extreme flood \\
\hline 2010 & & & & - & & & + & & & Extreme flood \\
\hline
\end{tabular}

Minus (-): End of El Niño.

Plus (+): Start of La Niña.

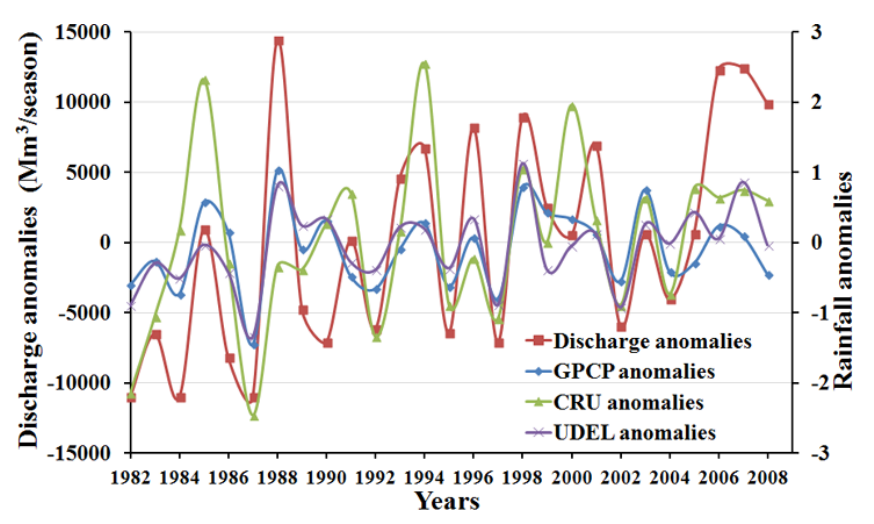

Fig. 8. Discharge anomalies at Eldiem station and GPCP, CRU and UDEL rainfall anomalies and over Ethiopian Highlands $\left(35^{\circ} \mathrm{E}\right.$, $40^{\circ} \mathrm{E}, 8^{\circ} \mathrm{N}, 13^{\circ} \mathrm{N}$ ) during JJAS from 1982 to 2008 .

relation between SST anomalies and precipitation. Figure 8 shows the JJAS rainfall anomalies over the upper catchment of the Blue Nile from 1982 to 2008 along with the discharge anomalies at Eldiem station. A varying correlation between GPCP, CRU, UDEL and discharge anomalies is found for 64,56 , and $74 \%$, respectively (Table 5), although the extreme discharge floods in 1988, 2006, 2007 and 2008 appear underestimated in all the rainfall data. This correlation indicates that the GPCP, CRU and UDEL data sets are generally representative of the precipitation variability over the region.

Figure 9 shows the correlation between GPCP, CRU and UDEL precipitation anomalies over the Ethiopian Highlands and Eldiem discharge with the Niño 3.4 SST anomalies for the entire analysis period and for different seasons. The CRU rainfall anomalies which showed the lowest correlation (Table 5) with the discharge anomalies at Eldiem station, it showed the highest correlation with Niño 3.4 index during the early seasons (JFM, FMA and MAM), Eldiem station showed the lowest correlation and insignificant correlation during this period. However, during MJJ up to ASO, CRU showed the lowest correlation with Niño 3.4, whereas the other rainfall (GPCP and UDEL) and discharge data set showed a higher correlation with Niño 3.4 anomalies during the same period (MJJ-ASO). The correlations between
Table 5. The correlation between the discharge anomalies at Eldiem station and GPCP, CRU and UDEL rainfall anomalies and over the Ethiopian Highlands $\left(35^{\circ} \mathrm{E}, 40^{\circ} \mathrm{E}, 8^{\circ} \mathrm{N}, 13^{\circ} \mathrm{N}\right)$ during JJAS from 1982 to 2008 .

\begin{tabular}{cccc}
\hline & $\begin{array}{c}\text { GPCP and } \\
\text { discharge }\end{array}$ & $\begin{array}{c}\text { CRU and } \\
\text { discharge }\end{array}$ & $\begin{array}{c}\text { UDEL and } \\
\text { discharge }\end{array}$ \\
\hline Correlation & 0.64 & 0.56 & 0.74 \\
\hline
\end{tabular}

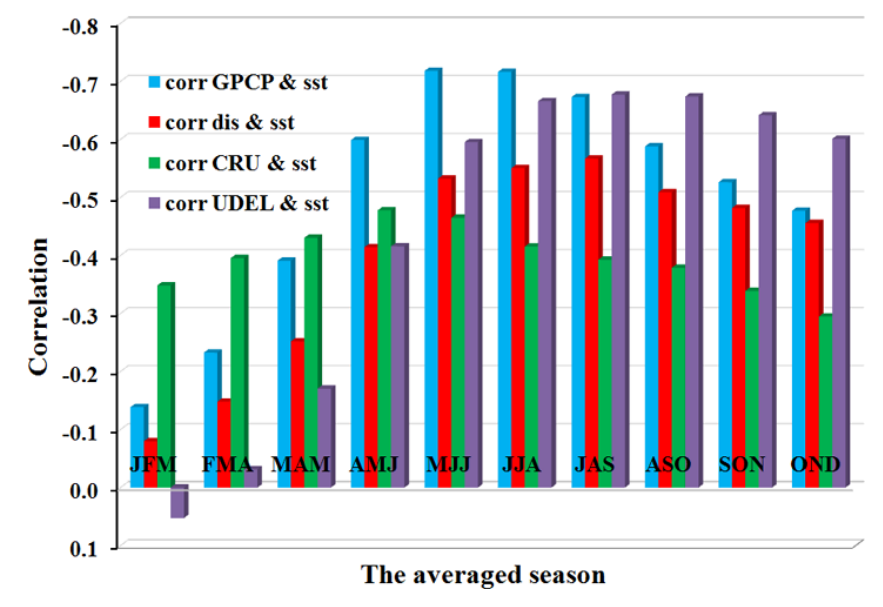

Fig. 9. Correlation between SST anomalies in Niño 3.4 region and the discharge anomalies at Eldiem station and the GPCP, UDEL and CRU rainfall in the upper catchment of the Blue Nile in the Ethiopian Highlands from 1982 to 2009.

GPCP and UDEL rainfall anomalies and Niño 3.4 index are maximum in magnitude in the AMJ through ASO season compared to the Blue Nile flow at Eldiem station. The correlations are higher for the precipitation than for the discharge except for the CRU data set. There is thus a potential use for the precipitation data set in the hydrological forecasting. Therefore the ENSO information, with the use of precipitation anomalies, may improve the hydrological prediction.

The corresponding two-tailed $t$ test values are then reported in Fig. 10, which also gives the threshold for statistical significance at the $95 \%$ confidence level. We find a negative 


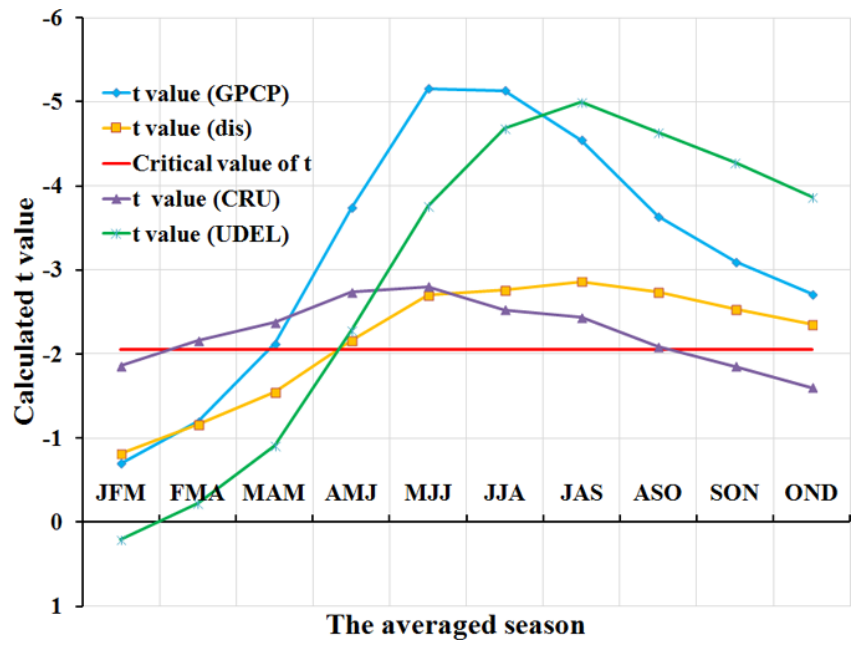

Fig. 10. $95 \%$ significance test of the correlation between SST anomalies in Niño 3.4 region and the GPCP, CRU, UDEL and discharge.

correlation in all seasons, indicating that a positive (negative) SST anomaly, or El Niño (La Niña) conditions, tends to lead to drought (flood) conditions. The correlations are maximum in magnitude in the AMJ through ASO seasons, or the late spring late summer period, and tend to decrease in the earlier and later seasons. Also, the correlations are higher for precipitation than for discharge except for the CRU data set during summer, and they show a different seasonal peak (MJJ for GPCP, AMJ for CRU and JJA for UDEL and discharge). Figure 10 shows that for all these seasons the correlations are significant at the $95 \%$ confidence level, with higher significance for precipitation. These figures thus confirm the strong effect of El Niño anomalies on the hydrology of the Ethiopia Highlands, which feed the Blue Nile River.

\section{Summary and conclusions}

Rainfall has a great impact on the social and economic life in the Ethiopian region and upper Nile catchment. Scarcity in rainfall leads to drought while excessive, intense rainfall may lead to flood. Ethiopian rainfall is highly variable, both temporally and spatially, and the rainfall seasonality varies greatly from one region to another (Gissila et al., 2004). The Blue Nile contributes about $60-69 \%$ to the main Nile discharge (Dumont, 1986).

Compared to previous studies, our analysis highlights the impact of timing and sequence of El Niño and La Niña on the drought and flood conditions over the upper catchment of the Blue Nile. This paper also highlights the role of Pacific SST anomalies in shaping the potential predictability of rainfall over tropical East Africa in both observational discharge at the mouth of the upper catchment of the Blue Nile and different observed precipitation data sets.
We find that that ENSO exerts a significant influence on the upper catchment of the Blue Nile. Droughts in the Blue Nile are sensitive to the timing of El Niño, with $80 \%$ of drought cases when El Niño starts in AMJ, JJA and JAS. The added value of including information about the timing of the start of El Niño is evident; when El Niño starts in AMJ, $83 \%$ of the cases resulted in drought. However, these results are based on a limited sample size (only six events). When the correlation calculated in our study and other studies Eltahir (1996) and Amarasekera et al. (1997) during AMJ of all years it varied between -0.36 and -0.39 . When El Niño ends early (DJF, JFM, FMA and MAM), there is almost no effect on the occurrence of drought in the Blue Nile. When El Niño terminates late in MJJ (or after that) there is a high possibility of drought occurrence in the Blue Nile. The added value to El Niño starting late in ASO (or after that) is that there is also no impact on the Blue Nile drought. However, when the correlation was calculated for the all years of ASO, it was -0.53. Eltahir (1996) and Amarasekera et al. (1997) also found high correlation during this season.

When La Niña started in AMJ, JJA and JAS, in $67 \%$ of the cases there was a flood or extreme flood. There has to be an active event El Niño/La Niña during the season for development of the monsoon over Ethiopia (May-September), for this teleconnection to have an impact. We also find that in $67 \%$ of the cases in which El Niño was followed by La Niña there were extreme floods in the Blue Nile.

The GPCP and UDEL rainfall anomalies showed the highest correlation with Niño 3.4 index during the AMJ through ASO season compared to the Blue Nile flow at Eldiem station, except for the CRU data set. So there is potential to use the precipitation data set in the hydrological forecasting using information about ENSO.

An important conclusion is that JJAS rainfall in the upper catchment of the Blue Nile is highly sensitive to the Niño 3.4 SST anomaly during the early season of AMJ in Niño 3.4. This season is recommended by this study to be used in the seasonal forecasting of the Blue Nile. We also find that El Niño being immediately followed by La Niña conditions is predictive of extreme flood conditions in the upper Nile catchment, information that may also be useful in forecasting extreme floods over the region. Future research will focus on using climate models to understand how this sequence of events may mechanistically impact floods and droughts on the Nile.

Acknowledgements. This work has been supported by the Earth System Physics (ESP) in the International Centre for Theoretical Physics (ICTP), the STEP program and the EU-funded collaborative DEWFORA project. The author would like to acknowledge Dr. Erika Coppola for her active discussion. Finally, I would like to thank all the staff of the ESP for their support, and the useful comments from the reviewers.

Edited by: F. Pappenberger 


\section{References}

Abtew, W., Melesse, A. M., and Dessalegne, T.: El Niño Southern Oscillation link to the Blue Nile River Basin hydrology, Hydrol. Process., 23, 3653-3660, doi:10.1002/hyp.7367, 2009.

Amarasekera, K. N., Lee, R. F., Williams, E. R., and Eltahir, E. A. B.: ENSO and the natural variability in the flow of tropical rivers, J. Hydrol., 200, 24-39, 1997.

Awadalla, A. G. and Rousselle, J.: Forecasting the Nile flood using sea surface temperatures as inputs: A comparison between transfer function with noise and neural networks, in: Proc. 19th AGU Hydrology Days, Fort Collins, CO, American Geophysical Union, 23-36, 1999.

Barnett, T. P., Graham, N. E., Cane, M. A., Zebiak, S. E., Dolan, S. C., O'Brien, J., and Legler, D. M.: On the prediction of the El Niño of 1986-1987, Science, 241, 192-196, 1988.

Barnston, A. G., van den Dool, H. M., Rodenhuis, D. R., Ropelewski, C. R., Kousky, V. E., O'Lenic, E. A., and Leetmaa, A.: Long-lead seasonal forecasts-Where do we stand?, B. Am. Meteorol. Soci., 75, 2097-2114, 1994.

Bhatt, U. S.: Circulation regimes of rainfall anomalies in the African-South Asian monsoon belt, J. Climate, 2, 1133-1144, 1989.

Camberlin, P.: Rainfall anomalies in the source region of the Nile and their connection with the Indian summer monsoon, J. Climate, 10, 1380-1392, 1997.

Camberlin, P., Janicot, S., and Poccard, I.: Seasonality and atmospheric dynamics of the teleconnection between African rainfall and tropical sea surface temperature: Atlantic vs. ENSO, Int. J. Climatol., 21, 973-1005, 2001.

Chen, D. and Cane, M. A.: El Niño prediction and predictability, J. Comput. Phys., 227, 3625-3640, 2008.

Chen, D., Cane, M. A., Kaplan, A., Zebiak, S. E., and Huang, D.: Predictability of El Niño over the past 148 years, Nature, 428, 733-736, 2004.

Conway, D.: A water balance model of the Upper Blue Nile in Ethiopia, Hydrolog. Sci. J., 42, 265-286, 1997.

Conway, D.: The climate and hydrology of the Upper Blue Nile River, Geogr. J., 166, 49-62, 2000.

De Putter, T., Loutre, M., and Wansard, G.: Decadal periodicities of Nile River historical discharge (AD 622-1470) and climatic implications, Geophys. Res. Lett., 25, 3193-3196, 1998.

Duethmann, D., Zimmer, J., Gafurov, A., Güntner, A., Kriegel, D., Merz, B., and Vorogushyn, S.: Evaluation of areal precipitation estimates based on downscaled reanalysis and station data by hydrological modelling, Hydrol. Earth Syst. Sci., 17, 2415-2434, doi:10.5194/hess-17-2415-2013, 2013.

Dumont, H. J.: The Nile River system, in: The Ecology of River Systems, edited by: Davies, B. R. and Walker, K. F., Kluwer, Dordrecht, 61-74, 1986.

Eldaw, A. K., Salas, J. D., and Garcia, L. A.: Long-range forecasting of the Nile River flows using climatic forcing, J. Appl. Meteorol., 42, 890-904, 2003.

Eltahir, E. A. B.: El Niño and the natural variability in the flow of the Nile River, Water Resour. Res., 32, 131-137, 1996.

Eltayeb, G. E.: Khartoum, Sudan, UN-HABITAT Case Studies, London, 1-20, 2003.
ESRL (Earth System Research Laboratory), USDC (U.S. Department of Commerce), Physical Sciences Division: Data available at: http://www.esrl.noaa.gov/psd/, last access: August 2013, 1900-2010.

Gissila, T., Black, E., Grimes, D. I. F., and Slingo, J. M.: Seasonal forecasting of the Ethiopian summer rains, Int. J. Climatol., 24, 1345-1358, 2004.

Gray, W. M., Christopher, W. L., Mielke Jr., P. W., and Berry, K. J.: Predicting Atlantic seasonal hurricane activity 6-11 months in advance, Weather Forecast., 7, 440-455, 1992.

Hastenrath, S., Polzin, D., and Camberlin, P.: Exploring the predictability of the "short rains" at the coast of East Africa, Int. J. Climatol., 24, 1333-1343, 2004.

Huffman, G. J., Bolvin, D. T., and Adler, R. F.: GPCP Version 2.2 Combined Precipitation Data set, WDC-A, NCDC, Asheville, NC, Data set, available at: http://www.ncdc.noaa.gov/oa/wmo/ wdcamet-ncdc.html (last access: October 2011), 2011.

Hulme, M. and Trilsbach, A.: The August 1988 storm over Khartoum: its climatology and impact, Weather, 44, 82-90, 1989.

Jury, M. R.: The coherent variability of African river flows: composite climate structure and the Atlantic circulation, Water SA, 29, 1-10, 2004.

Latif, M., Anderson, D., Barnett, T., Cane, M., Kleeman, R., Leetmaa, A., and Schneider, E.: A review of the predictability and prediction of ENSO, J. Geophys. Res., 103, 14375-14393, 1998.

Mitchell, T. D., Carter, T. R., Jones, P. D., Hulme, M., and New, M.: A comprehensive set of high-resolution grids of monthly climate for Europe and the globe: the observed record (1901-2000) and 16 scenarios (2001-2100), Tyndall Centre for Climate Change Research, Working Paper No. 55, 25 pp., 2004.

MOWRE: Flood Report 2011, Ministry of Water Resources and Electricity, Khartoum, Sudan, 2011.

Mutai, C., Ward, M., and Colman, A.: Towards the prediction of the East Africa short rains based on sea surface temperature atmosphere coupling, Int. J. Climatol., 18, 975-997, 1998.

Mwale, D. and Gan, T.: Wavelet analysis of variability, teleconnectivity, and predictability of September-November East Africa rainfall, J. Appl. Meteorol., 44, 256-269, 2005.

NOAA (National Weather Service): Monitoring and Data, Center for Weather and Climate Prediction, Maryland, USA, available at: http://www.cpc.ncep.noaa.gov/products/analysis_ monitoring/ensostuff/ensoyears.shtml, last access: August 2013, 2014.

Philippon, N., Camberlin, P., and Fauchereau, N.: Empirical predictability study of October-December east African rainfall, Q. J. Roy. Meteor. Soc., 128, 2239-2256, 2002.

Seleshi, Y.: Statistical analysis of the Ethiopian droughts in the XXth century based on monthly and yearly precipitation totals, M.S. thesis, Vrije Universiteit, Brussels, Belgium, 1991.

Seleshi, Y. and Zanke, U.: Recent changes in rainfall and rainy days in Ethiopia, Int. J. Climatol., 24, 973-983, 2004.

Sutcliffe, J. V., Dugdale, G., and Milford, J. R.: The Sudan floods of 1988, Hydrolog. Sci. J., 34, 355-364, 1989.

Teklu, T., von Braun, J., and Zaki, E.: Drought and Famine Relationships in Sudan: Policy and Implications, International Food Policy Research Institute (IFPRI), Washington, DC, USA, Research report No. 88, 140 pp., 1991.

Trenberth, K. E.: The definition of El Niño, B. Am. Meteorol. Soc., 78, 2771-2777, 1997. 
Vizy, E. and Cook, K.: Mechanisms by which Gulf of Guinea and eastern north Atlantic sea surface temperature anomalies can influence African rainfall, J. Climate, 14, 795-821, 2001.

Wang, G. and Eltahir, E. A. B.: Use of ENSO information in medium-and long-range forecasting of the Nile floods, J. Climate, 12, 1726-1737, 1999.

Whetton, P. and Rutherfurd, I.: Historical ENSO teleconnections in the Eastern Hemisphere, Climate Change, 26, 221-253, 1994.

Williams, A. P. and Funk, C.: A westward extension of the tropical Pacific warm pool leads to March through June drying in Kenya and Ethiopia, US Geol. Surv. Open File Report 2010-1199, 7 pp., 2010 .
Williams, A. P. and Funk, C.: Westward extension of the warm pool leads to a westward extension of the Walker circulation, drying eastern Africa, Clim. Dynam., 37, 2417-2435, doi:10.1007/s00382-010-0984-y, 2011.

Yeshanew, A. and Jury, M.: North African climate variability. Part 3: Resource prediction, Theor. Appl. Climatol., 89, 51-62, 2007.

Zaroug, M. A., Sylla, M. B., Giorgi, F., Eltahir, E. A., and Aggarwal, P. K.: A sensitivity study on the role of the swamps of southern Sudan in the summer climate of North Africa using a regional climate model, Theor. Appl. Climatol., 113, 63-81, 2013.

Zaroug, M. A. H., Giorgi, F., Coppale, E., and Eltahir, E. A. B.: Simulating the connections of ENSO and the hydrology of the Blue Nile using a climate model of the tropics, Hydrol. Earth Syst. Sci. Discuss., 11, 2233-2262, doi:10.5194/hessd-11-22332014, 2014. 